The Israeli Journal of Aquaculture - Bamidgeh, IIC:63.2011.605, 6 pages

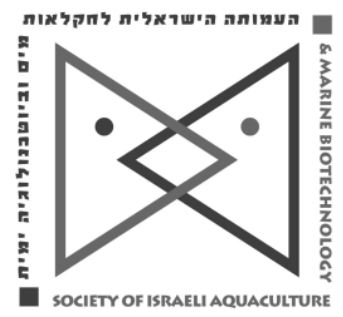

The IJA appears exclusively as a peer-reviewed on-line open access journal at http://www.siamb.org.il

Sale of IJA papers is strictly forbidden.

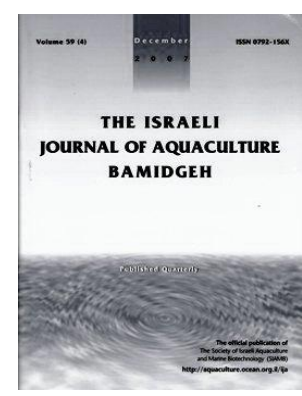

\title{
Replacement of Fishmeal by Rapeseed Protein Concentrate in Diets for Common Carp (Cyprinus carpio L.)
}

\author{
Hanno Slawski ${ }^{1,2} *$, Halime Adem ${ }^{3}$, Ralf-Peter Tressel ${ }^{3}$, \\ Klaus Wysujack ${ }^{4}$, Udo Koops ${ }^{4}$, Carsten Schulz ${ }^{1,2}$
}

${ }^{1}$ Gesellschaft für Marine Aquakultur mbH, Hafentörn 3, 25761 Büsum, Germany

${ }^{2}$ Department of Marine Aquaculture, Christian-Albrechts-Universität zu Kiel, Kiel, Germany

3 Pilot Pflanzenöltechnologie Magdeburg e.V., Berliner Chaussee 66, 39114 Magdeburg, Germany

${ }^{4}$ Johann Heinrich von Thünen-Institut, Federal Research Institute of Rural Areas, Forestry and Fisheries, Institute of Fisheries Ecology, Wulfsdorfer Weg 204, 22926 Ahrensburg, Germany

\section{(Received 1.7.10, Accepted 31.8.10)}

Key words: fishmeal alternative, Cyprinus carpio, glucosinolates, rapeseed protein concentrate

\begin{abstract}
The potential of rapeseed protein concentrate as an alternative to fishmeal in diets for common carp (initial average weight $26.7 \pm 0.8 \mathrm{~g}$ ) was evaluated. Triplicate groups of fish were fed isonitrogenous $(40.4 \pm 0.2 \%$ crude protein) and isocaloric $(21.4 \pm 0.1 \mathrm{~kJ} / \mathrm{g})$ experimental diets with $0 \%, 33 \%, 66 \%$, or $100 \%$ replacement of fishmeal by rapeseed protein concentrate. At the end of the 56-day feeding period, growth parameters and feed efficiencies did not significantly differ between fish fed the $0 \%$ and $33 \%$ diets. The $66 \%$ and $100 \%$ replacement diets led to reduced feed intake and feed efficiency, resulting in lower growth performance. It appears that the taste and amino acid profile of these diets were negatively affected by the high inclusion levels of rapeseed protein concentrate. In conclusion, rapeseed protein concentrate can effectively replace $33 \%$ of the fishmeal in diets for carp without using palatability enhancers or amino acid supplements.
\end{abstract}

* Corresponding author. E-mail: hanno.slawski@vti.bund.de 


\section{Introduction}

Wide availability, high protein content, and a desirable amino acid profile have caused rapeseed products to be considered as a fishmeal alternative in fish feeds. Products of rapeseed and its hybrid cultivar, canola, have been tested as protein sources in diets for rainbow trout (Thiessen et al., 2004), coho salmon (Higgs et al., 1979), chinook salmon (Higgs et al., 1983; Satoh et al., 1998), tilapia (Yigit and Olmez, 2009), channel catfish (Lim et al., 1998), silver perch (Booth and Allan, 2003), carp (Dabrowski and Kozlowska, 1981), red sea bream (Glencross et al., 2004), and turbot (Burel et al., 2000ab).

The nutritional quality of rapeseed products largely depends on their level of antinutritional factors. Prominent antinutritional factors in rapeseed are glucosinolates, phytic acid, phenolic constituents (e.g. tannins), and indigestible carbohydrates (Francis et al., 2001). Several processing techniques reduce the level of antinutrients in rapeseed (van Barneveld, 1998). Dehulling of seeds, use of high temperature and organic solvents (hexane) during oil extraction, and sieving of meal decrease glucosinolates, phytates, fibers, cellulose, hemicellulose, sinapin, and tannins (Anderson-Haferman et al., 1993; Mawson et al., 1993, 1994ab, 1995; Leming et al., 2004) and increase the protein level (Mwachireya et al., 1999). Protein extraction from meals by methanol-ammoniatreatment or ethanol-treatment further increases the protein level and removes glucosinolates, phenolic compounds, soluble sugars such as sucrose, and some oligosaccharides (Naczk and Shahidi, 1990; McCurdy and March, 1992; Chabanon et al., 2007) but also increases the level of non-digestible fiber (Mwachireya et al. 1999).

In the present study, liquid water extraction combined with ultrafiltration was used to increase the protein concentration of the final product and reduce non-digestible fibers. The resulting rapeseed protein concentrate (RPC) contained $71 \%$ crude protein. While rapeseed and canola protein products of similar quality are being produced in different countries for application in animal nutrition, these products are being produced for test purposes until their potential as protein sources for animal nutrition is clarified. Besides their nutritive quality, the costs of production will have to become low enough to make rapeseed and canola protein concentrates available at a competitive price compared to other protein sources such as fishmeal. Our RPC was tested as a replacement of fishmeal in pelleted diets for juvenile common carp to determine its limitations as a fish feed ingredient.

\section{Materials and Methods}

Diets. Solvent extracted rapeseed protein concentrate (RPC) was obtained from PPM, Magdeburg, Germany, where the rapeseed was cold pressed to extract most of the oil, residual oil was removed by a hexane treatment, and glucosinolates were extracted with an ethanol solution. PPM further processed the RPC by liquid water extraction, diafiltration and ultrafiltration of the proteins, and spray drying to produce PRC containing $71 \%$ crude protein (Table 1 ). Four test diets were formulated in which RPC replaced $0 \%, 33 \%, 66 \%$, or $100 \%$ of the fishmeal (Table 2 ). Vitamins and minerals were added to the diets to meet the dietary requirements of carp (NRC, 1993). The diets were passed through a pelleting press ( $L$ 14-175, Amandus Kahl, Reinbek, Germany) to obtain pellets of $4 \mathrm{~mm}$ diameter. The diets were isonitrogenous $(40.4 \pm 0.2 \%$ crude protein) and isocaloric $(21.4 \pm 0.1 \mathrm{~kJ} / \mathrm{g})$. Since this is the first of a series of consecutive feeding trials investigating the direct effects on feed quality of our RPC as a fishmeal replacement, diets were formulated without palatability enhancers or crystalline amino acids.

Growth trial. The growth trial was conducted at the Johann Heinrich von Thünen Institute of Fisheries Ecology in Ahrensburg, Germany. Common carp (Cyprinus carpio L.) were used as a model fish. In its juvenile stage, common carp has a high dietary protein requirement (Fine et al., 1996) making this relatively modest fish an ideal species for fishmeal replacement studies. Juvenile common carp that had been hatched in the institute were used. One week before the experiment started, twelve fish were stocked in each of twelve experimental tanks (70 l; bottom surface $480 \mathrm{~cm}^{2}$ ) that were part of a freshwater recirculation system. The tanks were provided with water at $1 \mathrm{l} / \mathrm{min}$, $23.8 \pm 0.7^{\circ} \mathrm{C}, 6.5 \pm 0.7 \mathrm{mg} \mathrm{O}_{2} / \mathrm{l}, \mathrm{pH} 7.0 \pm 0.7,<0.1 \mathrm{mg} \mathrm{NH}_{4}{ }^{+} / \mathrm{I}$, and $\left.<0.2 \mathrm{mg} \mathrm{NO}_{2}{ }^{-} / \mathrm{I}\right)$. The 
Table 1. Proximate composition (\% dry matter) and amino acid profile ( $\%$ of dietary protein) of fishmeal (FM) and rapeseed protein concentrate (RPC); antinutritional factors in RPC.

\begin{tabular}{|c|c|c|}
\hline & $F M$ & $R P C$ \\
\hline Dry matter (\%) & 91.6 & 94.2 \\
\hline Crude protein & 69.0 & 71.0 \\
\hline Crude fat & 7.0 & 2.2 \\
\hline Ash & 20.7 & 9.2 \\
\hline Crude fiber & 0.5 & 4.8 \\
\hline $\mathrm{NFE}^{\mathrm{a}}$ & 2.8 & 12.8 \\
\hline Gross energy $^{\mathrm{b}}(\mathrm{kJ} / \mathrm{g})$ & 19.9 & 25.2 \\
\hline \multicolumn{3}{|l|}{ Amino acids } \\
\hline Alanine & 6.41 & 4.70 \\
\hline Arginine & 5.84 & 7.49 \\
\hline Aspartic acid & 8.29 & 7.60 \\
\hline Cystine & 0.80 & 2.18 \\
\hline Glutamic & 12.47 & 17.80 \\
\hline Glycine & 8.13 & 5.29 \\
\hline Histidine & 2.00 & 2.99 \\
\hline Isoleucine & 3.63 & 4.29 \\
\hline Leucine & 6.46 & 7.81 \\
\hline Lysine & 6.55 & 5.70 \\
\hline Methionine & 2.37 & 2.03 \\
\hline Phenylalanine & 3.52 & 4.28 \\
\hline Prolin & 4.69 & 5.89 \\
\hline Serine & 4.06 & 4.40 \\
\hline Threonine & 3.90 & 4.44 \\
\hline Tryptophane & 0.84 & 1.42 \\
\hline Tyrosine & 2.62 & 3.28 \\
\hline Valine & 4.45 & 5.43 \\
\hline \multicolumn{3}{|l|}{ Antinutritional factors } \\
\hline Glucosinolates $(\mu \mathrm{mol} / \mathrm{g})$ & - & 0.2 \\
\hline Phytic acid $(\mathrm{mg} / \mathrm{kg})$ & - & $<500$ \\
\hline Tannins $(\mathrm{g} / 100 \mathrm{~g})$ & - & $<0.005$ \\
\hline \multicolumn{3}{|c|}{$\begin{array}{l}\text { Nitrogen free extract }=100-(\% \text { crude protein } \\
+\% \text { crude fat }+\% \text { ash }+\% \text { fiber }) \\
\text { b Calculated as } 23.9 \mathrm{~kJ} / \mathrm{g} \text { crude protein, } 39.8 \\
\mathrm{~kJ} / \mathrm{g} \text { crude fat, } 17.6 \mathrm{~kJ} / \mathrm{g} \mathrm{NFE}\end{array}$} \\
\hline
\end{tabular}

photoperiod was in accordance with the natural rhythm during February-April in our latitude $\left(53^{\circ} 41^{\prime} 0^{\prime \prime} \mathrm{N}\right)$. During adaptation, fish were fed the control diet in four daily meals until apparent satiation. After adaptation, fish were fasted for one day and the initial average weight $(26.7 \pm 0.8 \mathrm{~g})$ was determined. During the experiment, triplicate groups of 10 fish were fed the experimental diets in four daily meals (08:00, 11:00, 14:00, 17:00) to apparent satiation for 56 days. At the beginning and at end of the experiment, two fish per tank were removed and analyzed for proximate body composition.

Analysis. The diets and homogenized fish were analyzed for dry matter $\left(105^{\circ} \mathrm{C}\right.$, until constant weight), crude ash $\left(550^{\circ} \mathrm{C}, 2 \mathrm{~h}\right)$, crude fat (Soxtec HT6, Tecator, Höganäs, Sweden), and crude protein content ( $\mathrm{N} \times 6.25$; Kjeltec Auto System, Tecator, Höganäs, Sweden). The amino acid profiles of the diets were determined by infrared spectroscopy.

Calculations. Weight gain (\%) was calculated as 100 (final wt - initial wt)/initial wt, specific growth rate (\% per day) as 100 (In final body wt - In initial body wt)/days fed,

Table 2. Formulation, amino acid profile, and proximate composition of common carp diets replacement for fishmeal.

\begin{tabular}{|c|c|c|c|c|}
\hline \multirow[b]{2}{*}{ Ingredients $(\mathrm{g} / \mathrm{kg})$} & \multicolumn{4}{|c|}{ Replacement level (\%) } \\
\hline & 0 & 33 & 66 & 100 \\
\hline Herring meal ${ }^{a}$ & 240 & 160 & 80 & 0 \\
\hline Soy protein concentrate ${ }^{b}$ & 160 & 160 & 160 & 160 \\
\hline $\mathrm{RPC}^{\mathrm{c}}$ & 0 & 75 & 155 & 235 \\
\hline Wheat gluten ${ }^{d}$ & 150 & 150 & 150 & 150 \\
\hline Sunflower oil & 53 & 57 & 58 & 60 \\
\hline Rapeseed oil & 27 & 28 & 29 & 30 \\
\hline Dextrose & 150 & 150 & 148 & 145 \\
\hline Maize starch & 200 & 200 & 200 & 200 \\
\hline Vitamin-mineral mix & 20 & 20 & 20 & 20 \\
\hline \multicolumn{5}{|c|}{ Amino acids (\% of dietary protein) } \\
\hline Alanine & 4.59 & 4.31 & 4.14 & 3.95 \\
\hline Arginine & 5.38 & 5.53 & 5.75 & 6.00 \\
\hline Aspartic acid & 7.40 & 7.28 & 7.33 & 7.29 \\
\hline Cystine & 1.35 & 1.51 & 1.71 & 1.92 \\
\hline Glutamic acid & 21.45 & 22.01 & 22.92 & 23.80 \\
\hline Glycin & 5.57 & 5.12 & 4.72 & 4.39 \\
\hline Histidine & 2.27 & 2.37 & 2.48 & 2.63 \\
\hline Isoleucine & 3.89 & 4.02 & 3.85 & 4.02 \\
\hline Leucine & 6.94 & 7.07 & 7.25 & 7.52 \\
\hline Lysine & 4.67 & 4.34 & 3.80 & 3.24 \\
\hline Methionine & 1.84 & 1.75 & 1.69 & 1.63 \\
\hline Phenylalanine & 4.51 & 4.56 & 4.67 & 4.87 \\
\hline Prolin & 7.40 & 7.34 & 7.57 & 7.76 \\
\hline Serine & 4.43 & 4.29 & 4.67 & 4.76 \\
\hline Threonine & 3.38 & 3.37 & 3.56 & 3.68 \\
\hline Valine & 4.38 & 4.53 & 4.38 & 4.52 \\
\hline \multicolumn{5}{|l|}{ Proximate composition } \\
\hline Dry matter (\% wet wt) & 91.7 & 92.4 & 93.4 & 94.0 \\
\hline Crude protein (\%dry matter) & 40.4 & 40.1 & 40.6 & 40.5 \\
\hline Crude fat (\%dry matter) & 11.0 & 11.1 & 10.4 & 9.4 \\
\hline Ash (\%dry matter) & 7.6 & 6.3 & 5.3 & 4.1 \\
\hline Nitrogen free extract $(\mathrm{NFE})^{\mathrm{f}}$ & 41.0 & 42.5 & 43.7 & 46.0 \\
\hline Gross energy $(\mathrm{kJ} / \mathrm{g})^{\mathrm{g}}$ & 21.2 & 21.5 & 21.5 & 21.5 \\
\hline \multicolumn{5}{|c|}{$\begin{array}{l}\text { a VFC GmbH, Cuxhaven, Germany } \\
\text { b IMCOSOY } 60 \text { Piglet, IMCOPA, Araucaria, Brazil } \\
\text { c PPM, Magdeburg, Germany } \\
\text { d Euroduna-Technologies GmbH, Barmstedt, Germany } \\
\text { e AA-Mix } 517158 \& 508240 \text {, Vitfoss, Gråsten, Denmark } \\
\text { A NFE = } 100-(\% \text { crude protein }+\% \text { crude fat }+\% \text { ash + } \\
\text { \%fiber) } \\
\text { g Calculated as } 23.9 \mathrm{~kJ} / \mathrm{g} \text { crude protein, } 39.8 \mathrm{~kJ} / \mathrm{g} \text { crude fat, } \\
17.6 \mathrm{~kJ} / \mathrm{g} \text { NFE }\end{array}$} \\
\hline
\end{tabular}

${ }^{9}$ Calculated as $23.9 \mathrm{~kJ} / \mathrm{g}$ crude protein, $39.8 \mathrm{~kJ} / \mathrm{g}$ crude fat, $17.6 \mathrm{~kJ} / \mathrm{g}$ NFE 
feed conversion ratio as $\mathrm{g}$ dry feed intake/g wet body wt gain, protein efficiency ratio as $g$ wet body wt gain/g protein intake, gross energy intake as gross energy content in diet $\times \mathrm{g}$ dry feed intake, survival (\%) as 100 (initial fish count - dead fish count)/initial fish count.

Statistical analysis. Diets were assigned by a completely randomized design. Data were checked for normal distribution using Kolmogoroff Smirnov Test and eventually subjected to transformation. Data were analyzed by one-way analysis of variance (ANOVA) with "R" statistical software. When differences among groups were found, the differences in means were made with Tukey's Honestly Significant Difference test. Statistical significance was determined by setting the aggregate type I error at $5 \%$ $(p<0.05)$ for each set of comparisons. Data are presented as means \pm SD.

\section{Results}

Growth and feed efficiencies did not significantly differ between fish fed the control and $33 \%$ diets (Table 3 ). On the contrary, fish fed the $66 \%$ and $100 \%$ diets had significantly reduced growth performance and decreased feed efficiencies. There were no significant differences in whole body composition between treatments.

Table 3. Growth response, feed efficiencies, survival, and body composition of common carp juveniles fed diets containing rapeseed protein concentrate as a replacement for fishmeal (means $\pm S D, n=3$ ).

\begin{tabular}{|c|c|c|c|c|}
\hline & \multicolumn{4}{|c|}{ Replacement level (\%) } \\
\hline & 0 & 33 & 66 & 100 \\
\hline Initial wt (g) & $26.4 \pm 0.6$ & $26.7 \pm 0.6$ & $26.5 \pm 0.8$ & $27.2 \pm 1.3$ \\
\hline Final wt $(g)$ & $73.5 \pm 4.1^{\mathrm{a}}$ & $71.2 \pm 4.3^{\mathrm{a}}$ & $60.6 \pm 3.2^{b}$ & $49.7 \pm 2.3^{c}$ \\
\hline Wt gain $(\%)$ & $178.4 \pm 20.3^{a}$ & $167.0 \pm 17.3^{a}$ & $128.7 \pm 18.3^{b}$ & $83.3 \pm 16.3^{c}$ \\
\hline SGR (\%/day) & $1.83 \pm 0.13^{\mathrm{a}}$ & $1.75 \pm 0.12^{\mathrm{a}}$ & $1.47 \pm 0.15^{\mathrm{b}}$ & $1.08 \pm 0.16^{c}$ \\
\hline Feed intake & $51.5 \pm 4.11^{a}$ & $49.43 \pm 3.82^{a}$ & $42.20 \pm 2.47^{b}$ & $34.80 \pm 3.80^{c}$ \\
\hline Feed conversion ratio & $1.09 \pm 0.04^{\mathrm{a}}$ & $1.11 \pm 0.02^{\mathrm{a}}$ & $1.24 \pm 0.07^{b}$ & $1.56 \pm 0.14^{c}$ \\
\hline Protein efficiency ratio & $36.96 \pm 1.23^{\mathrm{a}}$ & $36.09 \pm 0.69^{a}$ & $32.72 \pm 1.95^{\mathrm{b}}$ & $26.18 \pm 2.36^{c}$ \\
\hline Gross energy intake $(\mathrm{kJ})$ & $109.2 \pm 10.7^{\mathrm{a}}$ & $106.3 \pm 10.1^{\mathrm{ab}}$ & $90.7 \pm 6.5^{b}$ & $74.8 \pm 10.0^{\mathrm{bc}}$ \\
\hline Survival (\%) & $96.7 \pm 5.8$ & $96.7 \pm 5.8$ & $93.3 \pm 5.8$ & $96.7 \pm 5.8$ \\
\hline \multicolumn{5}{|c|}{ Proximate whole body composition (\% wet wt)* } \\
\hline Moisture & $76.3 \pm 0.3$ & $75.9 \pm 0.3$ & $75.5 \pm 0.4$ & $75.3 \pm 0.4$ \\
\hline Crude protein & $16.7 \pm 0.3$ & $16.9 \pm 0.8$ & $17.2 \pm 0.5$ & $17.3 \pm 0.3$ \\
\hline Crude fat & $4.4 \pm 0.4$ & $4.3 \pm 0.5$ & $4.4 \pm 0.3$ & $4.2 \pm 0.3$ \\
\hline Ash & $2.1 \pm 0.2$ & $2.3 \pm 0.1$ & $2.4 \pm 0.1$ & $2.5 \pm 0.1$ \\
\hline
\end{tabular}

Means in a row with different superscripts significantly differ (Tukey's test; $p<0.05$ ).

*Initial body composition: moisture $75.7 \%$, crude protein $12.6 \%$, crude fat $2.6 \%$, ash $1.3 \%$

\section{Discussion}

Rapeseed protein concentrate is a viable alternative to fishmeal in fish feeds but antinutritional factors in rapeseed and canola affect its value for fish nutrition. Therefore, to achieve higher fishmeal replacement levels in fish diets, antinutritional factors in rapeseed protein concentrates should be greatly reduced. Our RPC had a high level of crude protein $(71 \%)$ and particularly low levels of glucosinolates, phytic acid, and tannins and successfully replaced $33 \%$ of the fishmeal protein from a control diet without retarding fish growth performance, feed intake, or feed efficiency. However, at $66 \%$ and $100 \%$ replacement levels, growth performance, feed intake, and feed efficiency decreased compared to the control. This contrasts with findings that replacement of $100 \%$ fishmeal protein by rapeseed meal protein in diets for common carp did not reduce weight gain or standard growth rate (Dabrowski and Kozlowska, 1981). We believe that $66 \%$ and $100 \%$ replacement negatively affected diet palatability and protein quality, and therefore limited fish growth performance. 
We observed that diets with high levels of RPC had diminished acceptance by the carp, documented by the lower feed intake in fish fed the $66 \%$ and $100 \%$ diets. The bitter taste exuded by glucosinolates and their breakdown products can retard diet acceptance in rainbow trout and turbot at dietary glucosinolate levels of $7.3 \mu \mathrm{mol} / \mathrm{g}$ and $18.7 \mu \mathrm{mol} / \mathrm{g}$, respectively (Burel et al., 2000bc). Because the RPC used in our study contained about $0.2 \mu \mathrm{mol} / \mathrm{g}$, the highest dietary glucosinolate concentration was 0.05 $\mu \mathrm{mol} / \mathrm{g}$, found in the $100 \%$ diet. We noticed a mustard smell in the $66 \%$ and $100 \%$ diets, resulting from high RPC inclusion. The smell clearly influenced diet acceptance by carp as RPC was the dominant protein source in the $66 \%$ and $100 \%$ diets. Diet acceptance by carp can probably be equalized by using several protein sources (blood meal, yeast, soyabean meal, barley meal as well as rapeseed meal), giving a more versatile diet taste (Dabrowski and Kozlowska, 1981).

Beside palatability problems, high dietary inclusion of RPC led to insufficient dietary amino acid concentrations for common carp. Diets high in RPC were low in lysine because of low or no inclusion of fishmeal or other protein source of animal origin. The lysine requirement of common carp is $5.7 \%$ of the dietary protein (Ogino, 1980). Although the control and $33 \%$ diets contained only $4.67 \%$ and $4.34 \%$ lysine, respectively, good growth results were obtained. However, the fast drop in growth rates in fish fed the $66 \%$ and $100 \%$ diets confirms the inappropriate quality of the dietary protein.

In conclusion, $33 \%$ of fishmeal in diets for common carp juveniles can be replaced by RPC. Consecutive feeding trials will clarify if higher levels can be replaced by our RPC by using palatability enhancers and amino acid supplements.

\section{Acknowledgements}

The project was financed by the European Fisheries Fund and the Zukunftsprogramm Fischerei des Landes Schleswig-Holstein.

\section{References}

Anderson-Hafermann J.C., Zhang Y. and C.M. Parsons, 1993. Effects of processing on the nutritional quality of canola meal. Poultry Sci., 72:326-333.

Booth M.A. and G.L. Allan, 2003. Utilization of digestible nitrogen and energy from four agricultural ingredients by juvenile silver perch Bidyanus bidyanus. Aquacult. Nutr., 9:317-326.

Burel C., Boujard T., Tulli F. and S.J. Kaushik, 2000a. Digestibility of extruded peas, extruded lupin, and rapeseed meal in rainbow trout (Oncorhynchus mykiss) and turbot (Psetta maxima). Aquaculture, 188:285-298.

Burel C., Boujard T., Kaushik S.J., Boeuf G., van der Geyten S., Mol K.A., Kuhn E.R., Quinsac A., Krouti M. and D. Ribaillier, 2000b. Potential of plant-protein sources as fishmeal substitutes in diets for turbot (Psetta maxima): growth, nutrient utilisation and thyroid status. Aquaculture, 188:363-382.

Burel C., Boujard T., Escaffre A.M., Kaushik S.J., Boeuf G., Mol K., van der Geyten S. and E.R. Kühn, 2000c. Dietary low glucosinolate rapeseed meal affects thyroid status and nutrient utilization in rainbow trout (Oncorhynchus mykiss). Brit. J. Nutr., 83:653664.

Chabanon G., Chevalot I., Framboisier X., Chenu S. and I. Marc, 2007. Hydrolysis of rapeseed protein isolates: kinetics, characterization and functional properties of hydrolysates. Process Biochem., 42:1419-1428.

Dabrowski K. and H. Kozlowska, 1981. Rapeseed meal in the diet of common carp reared in heated waters. I. Growth of fish and utilization of the diet. pp. 263-274. In: K. Tiews (ed.). Aquaculture in Heated Effluents and Recirculation Systems. Heenemann, Hamburg.

Fine M., Zilberg D., Cohen Z., Degani G., Moav B. and A. Gertler, 1996. The effect of dietary protein level, water temperature and growth hormone administration on growth and metabolism in the common carp (Cyprinus carpio). Comp. Biochem. Physiol. A, 114:35-42. 
Francis G., Makkar H.P.S. and K. Becker, 2001. Antinutritional factors present in plant-derived alternate fish feed ingredients and their effects in fish. Aquaculture, 199:197-227.

Glencross B., Hawkins W. and J. Curnow, 2004. Nutritional assessment of Australian canola meals. I. Evaluation of canola oil extraction method and meal processing conditions on the digestible value of canola meals fed to the red seabream (Pagrus auratus, Paulin). Aquacult. Res., 35:15-24.

Higgs D.A., Markert J.R., MacQuarrie D.W., McBride J.R., Dosanjh B.S., Nichols C. and G. Hoskins, 1979. Development of practical dry diets for coho salmon, Oncorhynchus kisutch, using poultry-by-product meal, feather meal, soybean meal and rapeseed meal as major protein sources. In: J.E. Halver, K. Tiews (eds.). Proc. World Symp. Fish Nutrition and Fishfeed Technology, vol. 11. 1978, Hamburg.

Higgs D.A., Fagerlund U.H.M., McBride J.R., Plotnikoff M.D., Dosanjh B.S., Markert J.R. and J. Davidson, 1983. Protein quality of Altex canola meal for juvenile chinook salmon (Oncorhynchus tshawytscha) considering dietary protein and 3,5,3'triiodo-L-thyronine content. Aquaculture, 34:213-238.

Leming R., Lember A. and T. Kukk, 2004. The content of individual glucosinolates in rapeseed and rapeseed cake produced in Estonia. Agraaeteadus, 15:21-27.

Lim C., Klesius H. and D.A. Higgs, 1998. Substitution of canola meal for soybean meal in diets for channel catfish Ictalurus punctatus. J. World Aquacult. Soc., 29:161-168.

Mawson R., Heaney R.K., Zdunczyk Z. and H. Kozlowska, 1993. Rapeseed meal glucosinolates and their antinutritional effects. Part 1. Rapeseed production and chemistry of glucosinolates. Die Nahrung, 37:131-140.

Mawson R., Heaney R.K., Zdunczyk Z. and H. Kozlowska, 1994a. Rapeseed meal glucosinolates and their antinutritional effects. Part 3. Animal growth and performance. Die Nahrung, 38:167-177.

Mawson R., Heaney R.K., Zdunczyk Z. and H. Kozlowska, 1994b. Rapeseed meal glucosinolates and their antinutritional effects. Part 4. Goitrogenicity and internal organs abnormalities in animals. Die Nahrung, 38:178-191.

Mawson R., Heaney R.K., Zdunczyk Z. and H. Kozlowska, 1995. Rapeseed meal glucosinolates and their antinutritional effects. Part 7. Processing. Die Nahrung, 39:3241.

McCurdy C.M. and B.E. March, 1992. Processing of canola meal for incorporation in trout and salmon diets. J. Am. Oil Chem. Soc., 69:213-220.

Mwachireya S.A., Beames R.M., Higgs D.A. and B.S. Dosanjh, 1999. Digestibility of canola protein products derived from the physical, enzymatic and chemical processing of commercial canola meal in rainbow trout, Oncorhynchus mykiss (Walbaum) held in fresh water. Aquacult. Nutr., 5:73-82.

Naczk M. and F. Shahidi, 1990. Carbohydrates of canola and rapeseed. pp. 211-220. In: F. Shahidi (ed.). Canola, Rapeseed: Production, Chemistry, Nutrition \& Processing Technology. Van Nostrand Reinhold, New York.

NRC, 1993. Nutrient Requirements of Fish. National Research Council, National Academy Press, Washington, DC.

Ogino C., 1980. Protein requirement of carp and rainbow trout. Bull. Jpn. Soc. Sci. Fish., 46:171.

Satoh S., Higgs D.A., Dosanjh B.S., Hardy R.W., Eales J.G. and G. Deacon, 1998. Effect of extrusion processing on the nutritive value of canola meal for chinook salmon (Oncorhynchus tshawytscha) in seawater. Aquacult. Nutr., 4:115-122.

Thiessen D.L., Maenz D.D. and R.W. Newkirk, 2004. Replacement of fishmeal by canola protein concentrate in diets fed to rainbow trout (Oncorhynchus mykiss). Aquacult. Nutr., 10:379-388.

van Barneveld R.J., 1998. Influence of Oil Extraction Method on the Nutritional Value of Canola Meal for Growing Pigs. Project DAS38-1188, Pig Research and Development Corporation, Canberra. 46 pp.

Yigit N.O. and M. Olmez, 2009. Canola meal as an alternative protein source in diets for fry of tilapia (Oreochromis niloticus). Isr. J. Aquacult. - Bamidgeh, 61(1):35-41. 